\title{
Distribution and ecology of the saproxylic hoverfly Chalcosyrphus eunotus (Loew, 1873) (Diptera: Syrphidae) in Poland
}

\author{
Agnieszka SoszyńsKA-MAJ*, Bogusław SosZYŃSKI** and Anna KLASA*** \\ *Department of Invertebrate Zoology and Hydrobiology, University of Lódź, ul.Banacha 12/16, 90-237 Lódż, Poland; \\ e-mail: agasosz@biol.umi.lodz.pl \\ ** Field Center of Ecological Education and Culture, ul. Okólna 183, 91-520 tódź, Poland; \\ e-mail: eusosz@retsat1.com.pl \\ ***Ojców National Park,32-047 Ojców, Poland, e-mail: anna_klasa@wp.pl
}

\begin{abstract}
Chalcosyrphus eunotus is one of the most endangered saproxylic hoverflies in Poland. Almost 80 years since its first record in Pomerania, this fly has been found in a few new localities in Poland: Ojców National Park, Bialowieża Primeval Forest, and in the vicinity of following cities: Torun, Gdansk, Lódź and Inowłódz. The actual map of its range in Poland is presented and the current state of knowledge of its phenology, ecology, behavior and conservation status is discussed. The authors advance the hypothesis that the increasing occurrence of $C h$. eunotus is directly proportional to an increase in the number of beavers over the last 20 years.
\end{abstract}

Key words: hoverflies, saproxylic indicator, streams, semi-submerged wood, beavers, protection

\section{INTRODUCTION}

There are ca 400 species of Syrphidae recorded from Poland. These flies represent a wide spectrum of biological characteristics. There are phytophagous, mycophagous, zoophagous and as well as aquatic and terrestrial saprophagous species. Eighty-two species of hoverflies living in Poland are saprophagous, and most of them (65 species) are saproxylic - a group of insects extremely endangered due to larval habitat loss (Soszyński et al. 2000, Soszyński 2007).

In Poland the genus Chalcosyrphus Curran includes six species, closely associated with sub-merged wood deposited in water. Among them four species are listed on the Red List of Threatened Animals in Poland (Palaczyk et al. 2002). Chalcosyrphus eunotus is the most endangered species. The species is threatened in many countries in Europe (Speight et al. 2008) and listed in the highest threat category (CR) in Poland (Palaczyk et al. 2002). Its larvae live in logs and below the bark of logs lying in streams flowing through deciduous forests. The biology of this species has been studied by Maibach \& Goeldlin (1992). In Poland Ch. eunotus was recorded only from Pomerania (Karl 1935) and then considered as probably extinct (Soszyński et al. 2000). Since 2001, almost 80 years after the first record, it has been found in two new sites (Renema 2001, Kowalczyk 2004). Taking into account the latest data on $C h$. eunotus distribution, the authors decided to verify the opinion that this species is extraordinarily rare in Poland.

\section{MATERIAL EXAMINED}

Flies were collected using a sweeping net. The material included a total of 11 specimens collected and three faunistic records from literature (Karl 1935, Renema 2001, Kowalczyk 2004). All records were coded using the Universal Transverse Mercator (UTM) coordinate system. A map of the present distribution of $C h$. eunotus was made with Gnomon software based on the UTM data. The specimens were deposited in the Museum of Ojców National 
Park, collection of the Department of Invertebrate Zoology and Hydrobiology in University of Łódź and in private collection of Bogusław Soszyński.

Literature data: Baltic Coast: Gdynia-Polana Krykulec [CF34], 28.05.2003, 2 ठ (Kowalczyk 2004); Pomerania Lake Region: Łysomice near Słupsk [XA42], 25.05.1923, 2 ㅇ (Karl 1935); Białowieża Primeval Forest: Białowieża [FD94], 4.06.1998, 1 ㅇ (Renema 2001).

New data: Pomerania Lake Region: Zbocza Phutowskie Res. near Toruń [CE20], 17.05.2003, $2 \hat{\jmath} \hat{\jmath}$, leg. K. Szpila; Kraków-Wieluń Upland: Dolina Sąspowska in Ojców National Park [DA16], 13.05.2002, 1 j, leg. A. Klasa; Małopolska Upland: Grądy nad Lindą Res. [CC84], 13.05.2006, $3 \hat{\jmath} \widehat{\jmath}, 2$ 우, leg. A. Soszyńska-Maj; 11.05.2008 $2 \hat{\jmath} \delta$, leg. T. Maj; Ceteńka Spring (proposed nature reserve) near Inowłódz [DC 50], 18.04.2008, 1 †, leg, M. Soszyński.

Short descriptions of the study sites are presented below.

- Zbocza Płutowskie Res. near Toruń [CE20]. The nature reserve is situated on a high and steep hillside of the Wisła (Vistula) valley, protecting xerothermic vegetation.

- Dolina Sąspowska in Ojców National Park [DA16]. Sąspówka stream, a right tributary of the Prąnik River, is a small mountain stream fed by a limestone spring. A large amount of decaying wood is deposited in the river bed.

- Grądy nad Lindą Res. near Lódź [CC84]. The reserve protects a valley of the stream Linda and its small tributary with natural deep meandering beds. An old tree-stand grows on the narrow strip of the valley. There are few sites with decaying wood debris lying in the water.

- Ceteńka Spring (proposed res.) near Inowłódz [DC 50]. Ceteńka is a right tributary of the Pilica River. The proposed nature reserve would protect a section of the small valley famous for numerous seepages of water from the soil, springs and ravines $(8 \mathrm{~m}$ deep) (Kurowski et al. 2008)..

\section{DISTRIBUTION AND ECOLOGY}

The current distribution of Ch. eunotus in Poland based on UTM data is presented on the map below (Fig. 1).

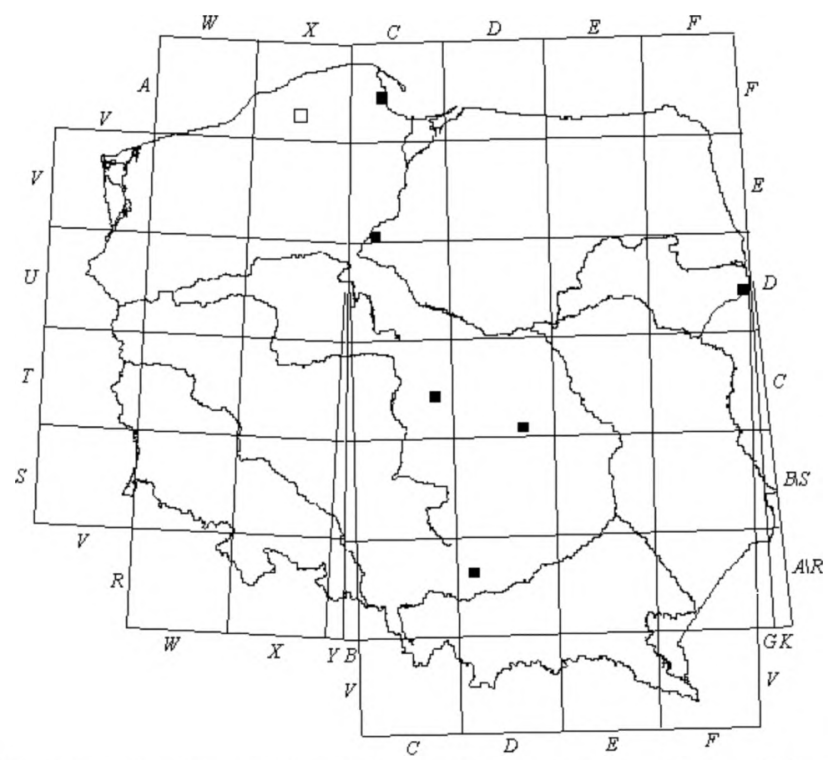

Fig. 1. Distribution of Chalcosyrphus eunotus in Poland. Explanation: $\square-$ record from 1923; $\mathbf{\square}$ - records from years 1998-2008 


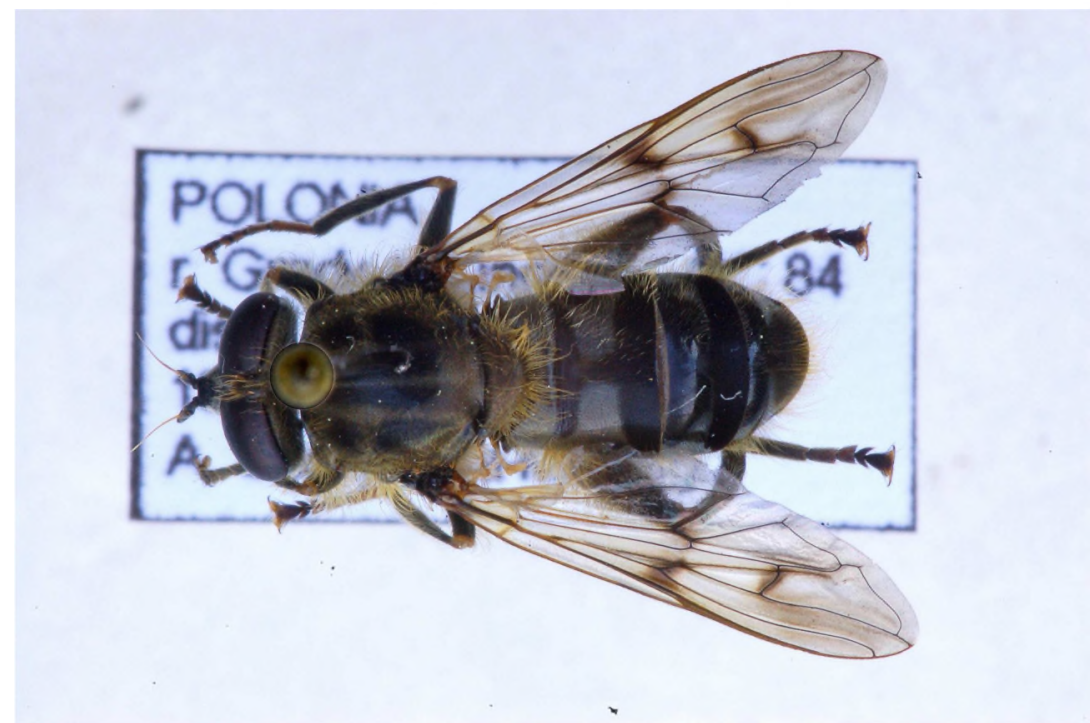

Fig. 2. Male of Chalcosyrphus eunotus (photo A. Palaczyk).

Ch. eunotus (Fig. 2) is listed as a saproxylic indicator and stenotopic species, closely associated with natural, unregulated stream channels. The larvae live in decaying wood deposited in water. Imagines have been found along the edges of streams flowing through the deciduous forest (Quercus-Fraxinus-Ulmus) resting on partially submerged logs (Renema 2001). Ch. eunotus is known from a few localities in the Netherlands, France, Germany, Serbia and also from one or two records in Belgium, Spain, Switzerland, Croatia, Republic of Macedonia, Romania and Slovakia. It has lately been found in the Czech Republic (Mazanek et al. 1999) and Turkey (Saribiyik 2009).

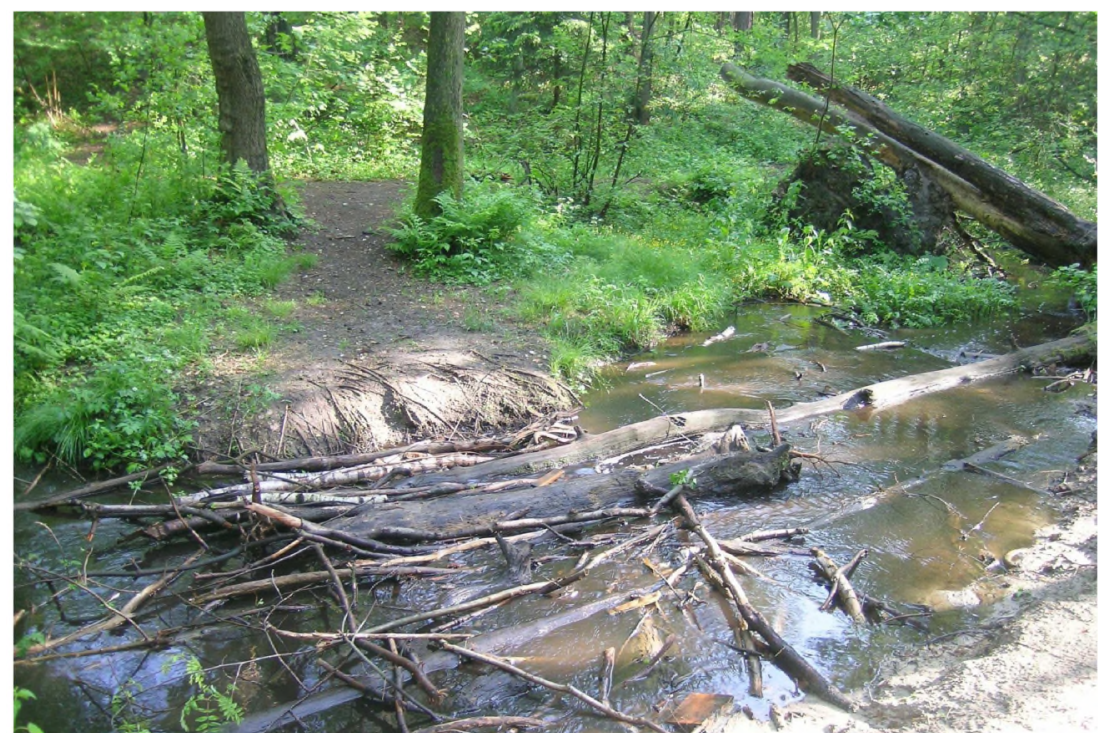

Fig. 3. Habitat of Chalcosyrphus eunotus on the Linda stream (photo A. Soszyńska-Maj). 
Most catches (in terms of individuals and sampling sites) have come from Great Britain (Renema 2001, Boardman 2005). The easternmost record of this species has been in Armenia (Peck 1988). In Poland, before 2001, Ch. eunotus was known only from Pomerania (Karl 1935).

Since 2001, the number of its records in Poland has slightly increased (Renema 2001, Kowalczyk 2004, this paper). In Poland this hoverfly has been reported from the edges or close vicinity of forest streams and rivers. At one site it was found during mating (Grądy nad Linda res.) (Fig. 3). Numerous individuals of $\mathrm{C} h$. eunotus were observed flying only above the logs lying in the stream in dappled shade. None were found near fallen trees in deep shade. Males and females were flying close to water surface and copulating in the air (caught in sweeping net in copula). Male territoriality was observed, with escaping flies repeatedly returning to the same place on the log. Such observation of territoriality was earlier made by Schmid (1996). The most numerous catches of $C h$. eunotus in Poland were related to its activity peak and occurred in mid-May, while in the rest of Europe the flight period lasted from April to July (Speight 2008).

Semi-submerged wood, preferred by $C h$. eunotus, is an extremely threatened habitat. In Poland it is abundant mainly in nature reserves and national parks. It is possible that this fly found allies in beavers, whose number has increased significantly in the last 20 years. The majority of the new records have been in the vicinity of beaver refuges (Zbocza Plutowskie res., Ojców National Park, Białowieża Primeval Forest, Trójmiejski Landscape Park near Gdańsk-Oliwa). As a result of water-damming by those rodents, large stretches of forest are inundated. The beavers also cut and submerge trees and branches as a store of winter food, creating habitats where Ch. eunotus larvae can develop. However, in Grądy nad Lindą res. the flies were observed near logs and branches lying in water, placed and used by people as a bridge. In Shropshire (England), Ch. eunotus was recorded on logs in a stream in dingle woodland (Boardman 2005). The author suggested that classic dingle woodland is a typical breeding habitat for this hoverfly as well as for the Lipsothrix group of flies and many others. Apart from the genus Chalcosyrphus, few other species of Diptera endangered in Poland are strictly associated with the habitat of semi-submerged wood. The examples are Lejota ruficornis (Zetterstedt, 1843) and species of the genus Xylota, which are very rare in Poland or even recently extinguished. Such biotopes are also critically threatened throughout Europe. Unfortunately, fallen trees, logs and branches are frequently removed from rivers to reduce the risk of flooding, while dead wood is removed from forest. Both habitats are sources of future coarse woody debris (CWD). In the UK, Godfrey and Middlebrook (2007) identified 147 invertebrate saprobiontic species strongly associated with CWD, with biology similar to $C h$. eunotus.

The present state of knowledge about the distribution of $C h$. eunotus in Poland shows that this species is not as critically threatened as has been thought. Moreover, this hoverfly could be under-recorded because of its early flight period - the earliest record in Polish came from midApril. However, it should still be classified as a threatened species in CR category. The authors hypothesise that the increasing occurrence of $\mathrm{Ch}$. eunotus could be directly related to the increasing number of beavers. If the increasing tendency continues, the status of Ch. eunotus should be transferred to a lower category of threats - endangered (EN) or vulnerable (VU) according to IUCN rules governing the classification of taxa to appropriate categories (IUCN 2001).

\section{ACKNOWLEDGEMENTS}

We are grateful to Michal Grabowski for correcting the English version of the manuscript. 


\section{REFERENCES}

BOARDMAN P. 2005. The Red Data Book Invertebrates of Shropshire, a compilation and review of data. Shropshire Biodiversity Partnership, http://www.naturalshropshire.org.uk

GODFREY A. \& MIDDLEBROOK I. 2007. Invertebrates associated with coarse woody debris in stream and rivers in Britain. British Wildlife 18 (3): 178-183.

IUCN. 2001. IUCN Red List Categories and Criteria: Version 3.1. IUCN Species Survival Commission. IUCN, Gland, Switzerland and Cambridge, UK. ii $+30 \mathrm{pp}$.

KARL O. 1935. Die Fliegenfauna Pommerns Diptera, Brachycera. Stettin. Ent. Ztg., Stettin, 96 (2): $242-261$.

KowalczYK J. K. 2004. Polana Krykulec w Trójmiejskim Parku Krajobrazowym (TPK) ważną ostoją rzadkich gatunków owadów. Gawron 1 (30): 24-28.

KUROWSKI J. K., KIEDRZYŃSKI M., LUCZAK M. \& GIELNIAK P. 2008. Śródleśne źródliska - problemy waloryzacji i ochrony na przykładzie regionu tódzkiego. Studia i Materiały Centrum Edukacji Przyrodniczo-Leśnej 2 (18): $218-235$.

MAZANEK L., BARTAK M. \& DOLĚZAL Z. 1999. Faunistic notes: Syrphidae. Dipterologica bohemoslovaca 9: 194-198.

MAIBACH A. \& GOELDLN DE TIEFENAU P. 1992. Description de la pupe de Chalcosyrphus (Xylotodes) eunotus (Loew) et synthèse des caractéristiques morphologiques des stades immatures de plusieurs genres de la tribu des Xylotini (Diptera, Syrphidae). Mitteilungen der Schweizerischen Entomologischen Gesellschaft 65: 165-175.

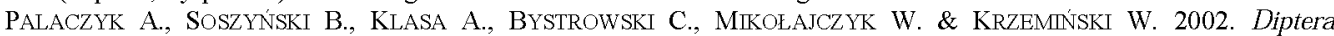
Muchówki. Red List of Threatened Animals in Poland, pp. 38-44. Instytut Ochrony Przyrody PAN, Kraków, 155 pp.

PECK L. V. 1988. Family Syrphidae. In: SOOs A. (ed.), Catalogue of Palearetic Diptera, Vol. 8. Syrphidae Conopidae, pp. 11-230. Akadémiai Kiadó Budapest, 383 pp.

RENEMA W. 2001. Drie maal is scheepsrecht, de zweefvlieg Chalcosyrphus eunotus terug op de nederlandse lijst (Diptera: Syrphidae). Nederlandse Faunistische Mededelingen 15: 111-115.

SARIBIYIK S. 2009. Several Rarely Found New Records for the Turkish Syrphidae Fauna (Diptera: Syrphidae). Journal of the Entomological Research Society 11 (3): 37-40.

SCHMD U. 1996. Aut gläsernen Schwingen: Schwebfliegen. Stuttgarter Beiträge zur Naturkunde, serie C, 40: 1-80.

SOSZYŃSKi B. 2007. Bzygowate (Syrphidae). IN: BOGDANOWICZ W., CHUDZICKA E., PLIPIUK I. \& SKIBIŃSKA E. (eds), Fauna of Poland - characteristics and checklist of species. Vol. 2, pp. 102-105. Muzeum i Instytut Zoologii PAN, Warszawa, $506 \mathrm{pp}$.

SOSZYŃSKi B., PALACZYK A. \& KRZEMnT́SKI W. 2000. Zagrożenia i perspektywy ochrony muchówek (Diptera) w Polsce. Wiadomości Entomologiczne 18, supl. 2: 165-176.

SPEIGHT M. C. D. 2008. Species accounts of European Syrphidae (Diptera). In: SPEIGHT M. C. D., CASTELLA, E., SARTHOU J.-P. \& MONTEIL C. (eds), Syrph the Net, the database of European Syrphidae. Vol. 55, pp. 1-262, Syrph the Net publications, Dublin.

Speight M. C. D., CAstella E., SARThou J.-P. \& MONTEIL C. 2008. (eds), Syrph the Net, the database of European Syrphidae. Vol. 55. Syrph the Net publications, Dublin.

\section{STRESZCZENIE}

\section{[Rozmieszezenie i ekologia saproksylobiontycznej muchówki z rodziny bzygowatych Chalcosyrphus eunotus (Loew, 1873) (Diptera: Syrphidae) w Polsce]}

Chalcosyrphus eunotus to jeden $\mathrm{z}$ najbardziej zagrożonych wyginięciem gatunków saproksylobiontycznych $\mathrm{w}$ Polsce. Od 2001 roku, po ponad 80 latach od pierwszego stwierdzenia na Pomorzu, gatunek ten zostal zebrany na kilku nowych stanowiskach: $w$ Ojcowskim Parku Narodowym, Puszczy Bialowieskiej oraz w okolicach Torunia, Gdańska, Lodzi i Inowłódza. W pracy zaprezentowano aktualną mapę występowania tego taksonu $\mathrm{w}$ Polsce i obecny stan wiedzy o jego fenologii i ekologii. Autorzy postawili hipotezę o związku między rosnącą populacją bobrów w Polsce, a zwiększaniem się notowań Ch. eunotus. 